\title{
EFFECT OF CHEMICAL, BIO AND ORGANIC FERTILIZER TREATMENTS ON YIELD AND YIELD COMPONENTS OF SWEET POTATO (Ipomea batatas)
}

\author{
FOLY, H. M. H. ${ }^{1}$, H. S.TONY ${ }^{2}$ AND OMAR F. DAKHLE ${ }^{3}$.
}

1. Centeral Lab. of Organic Agri,,Hort.Dept., ARC, Ministry of Agric., Egypt.

2. Hort. Dept., ARC, Ministry of Agric., Egypt.

3. Genetic Dept., Fac of Agriculture, Minia Univ.

(Manuscript received 29 November 2011)

\begin{abstract}
Field experiments of the present study were carried out during the two successive seasons of 2008 and 2009 at Research Farm of Faculty of Agriculture, Minia University, EL - Minia, Egypt. Sweet potato c.v. "Mabrouka" was cultivated to study effect of the chemical NPK, bio and organic fertilizers on its yield and yield components under EL-Minia growing conditions. Eight treatments were studied with some possible combinations among the used fertilizers. The obtained results of the present study could be summarized as follow: Number of storage - roots/plant was significantly affected by fertilizers treatments in both seasons. The highest numbers of roots were produced from plants fertilized with compost only in the first season, while from the combined application of compost + half rate of the recommended NPK fertilizers + bio-fertilizers in the second season. The highest values of average root fresh weight were obtained from plants fertilized with half recommended rate of dose NPK + compost in the first season and the half recommended rate of the chemical NPK fertilizer in the second season. Data declared that the highest values of root dry weight per plant were obtained from plants fertilized with compost + bio-fertilizers in the first season and compost only in the second season. Significant effect on total dry weight per plant in both seasons was detected. The highest value in the first season was obtained from plants fertilized by half NPK + compost, while plants fertilized with the bio-fertilizers only gave the highest value, in the second season. Highest value of harvest index in the first season, was given with using the bio-fertilizers only, while half rate of NPK only produced the highest value in the second season. In general, the effects of organic and bio-fertilizers on most of the studied yield characters indicate the possibility of replacing or reducing the amount of the chemical NPK fertilizers required for sweet potato ( c.v. Mabrouka) production. Furthermore, Compost + bio-fertilizers treatments exceeded the recommended NPK treatment of some economically important studied characters such as number of storage roots / plant and average root fresh weight/ Plant.
\end{abstract}




\section{INTRODUCTION}

Sweet potato (Ipomea batatas (L.) is very important vegetable crop food in many countries including Egypt. It is a member of the family Convolvulaceae,

in which there are over 400 Ipomea species distributed throughout the tropics, but sweet potato is the only one of economic importance (MacDonald ,1963).

Biofertilizers, which can be defined as preparations containing live cells of efficient strains of nitrogen fixing organisms or phosphate solublizing bacteria which could be used instead of chemical fertilizers ( Subba Roa , 1984 ).

Organic fertilizers such as plant compost play an important role in sweet potato production. Organic fertilizers improve soil structure, which encourage the plant to produce good roots and improving aeration in the soil (Abou-Hussein, et. al., 2002).

Nwinyi (1988) conducted a study comparing fertilizing sweet potato plants by given no fertilizer or $45 \mathrm{~kg} \mathrm{~N}+15 \mathrm{~kg} P+70 \mathrm{~kg} \mathrm{k} / \mathrm{ha}$ or $70 \mathrm{~kg} \mathrm{~N}+70 \mathrm{~kg} P+140 \mathrm{~kg} \mathrm{k} / \mathrm{ha}$ 6 weeks after planting. The author found that tuber fresh weight and saleable tuber yield were markedly higher with the highest than with the lowest NPK rates. Syriac and Kunju (1989) reported that applying 50.75 or $100 \mathrm{~kg} \mathrm{~N}, 25,50$ or $75 \mathrm{~kg} \mathrm{P}_{2} \mathrm{O}_{5}$ and 50,75 or $100 \mathrm{~kg} \mathrm{~K} \mathrm{~K}_{2} \mathrm{O} / \mathrm{ha}$ in different combinations gave tuber yields of $6.89-13.76$ t/ha compared with $4.66 \mathrm{t}$ for the control. The application of N + P2O5 + K2O at $75+$ $75+75 \mathrm{~kg} / \mathrm{ha}$ gave the highest yield.

Marcano and Diaz (1994) declared that different rates of NPK fertilizers had no significant difference in fresh weight of commercially - acceptable tubers, total tubers and foliage. However, highest actual yields were given by the application of $30 \mathrm{~kg} \mathrm{~N}, 40 \mathrm{~kg} \mathrm{P}_{2} \mathrm{O}_{5}$ and $180 \mathrm{~kg} \mathrm{~K} 2 \mathrm{O} / \mathrm{ha}$. The low response to NPK was probably due to the moderately - good initial nutrient availability. The lowest rates of applied NPK gave $93 \%, 74 \%$ and $75 \%$ of maximum yields recorded for total tubers, commercial tubers and foliage, respectively.

Abou-Hussein et. al. (2002) found that increasing compost rate from $40 \mathrm{~m}^{3}$ to $60 \mathrm{~m}^{3}$ per plant increased plant height, fresh and dry weights of leaves and stems in potato C.v. "Nicola". Indiresh et. al. (2003) reported that application of 50\% NPK fertilizer with biofertilizer (Azotobacter chroococum and Pseudomonas striata) was the best in obtaining economically higher potato yield. Kleinhenz and Cardina (2003) reported that compost application increased sweet potato yield by $13-14 \%$.

Sarhan et. al. (2004) found that applying organic manure in addition to spraying with NPK foliar nutrients caused significant increases in the percentage of tuber dry matter in both seasons in potato c.v. "Spunta". Abou-Hussein (2005) found that application of compost at $10 \mathrm{t} /$ feddan increased yield of potato C.v. "Nicola" and increased the vegetative growth. 
El-Sayed et. al. (2007) reported that plants which fertilized with organic fertilization sources were better than those of the unfertilized ones. Fertilization with poultry manure (PM) followed by 50\% FYM $+50 \%$ PM significantly increased plant stem length, number of leaves, leaf area and foliage dry weight as well as total yield, number of tubers/plant and average of tuber weight.

Crossman and Hill (1987) found that inoculation of sweet potato with Azospirillum increased foliage weight, The yield of tuber roots was increased when sweet potato plant were inoculated with Azospirillum brasilense. Hill et. al., (1988) reported that nitrogen-fixing bacteria belonging to the Azospirillum genus were found in association with the roots of sweet potato. Desmond and Walter (1990) found that inoculation with Azospirillum increased sweet potato total and marketable yields by $12 \%$ and $17 \%$, respectively. Higher storage root yields were accompanied by lower foliage yields which suggested that the Azospirillum inoculation might enhance storage root growth at the expense of foliage growth in soils with low to moderate $\mathrm{N}$ levels (40 to $80 \mathrm{~kg} / \mathrm{ha}$ ). Furthermore, storage root yield was highest with the combined of $40 \mathrm{~kg} \mathrm{~N} / \mathrm{ha}$ with inoculation than with inoculation alone.

Rasco et. al. (1992) reported that storage root DW was increased by inoculation in some treatments. Jadhav et. al. (1998a) reported that the inoculation of sweet potato plants with Azotobacter or Azospirillum increased tuber yield. They also, revealed that the combined inoculations of both bacteria gave significantly higher yield than the single inoculations.

Jha and Mishra (1999) found that application of $40 \mathrm{~kg} \mathrm{~N} / \mathrm{ha}$ supplemented with 10kg Azospirillum /ha as a soil application produced the highest tuber yield (28.62 $\mathrm{t} / \mathrm{ha}$ ) followed by the application of $40 \mathrm{~kg} \mathrm{~N} / \mathrm{ha}$ supplemented with $2 \mathrm{~kg}$ Azospirillum as vine dipping plus $10 \mathrm{~kg}$ Azospirillums as soil application (27.54 t/ha) and 60kg N/ha alone $(27.40 \mathrm{t} / \mathrm{ha})$. The highest net income was obtained from $40 \mathrm{~kg} \mathrm{~N}+10 \mathrm{~kg}$ Azospirillum.

Pushpakumari and Geethakumari (1999) studied the effect of the inoculation with Azotobacter and vesicular arbuscular mycorrhiza (VAM) only or in combination with different $\mathrm{N}$ and $\mathrm{P}$ levels (100, 75 and 50\%). The $\mathrm{N}$ : P : K recommended rate was $75-50-75 \mathrm{~kg} / \mathrm{ha}$. Results revealed that treatments involving microbial inoculation were superior to those without microbial inoculation at all levels of nutrients. A higher efficiency was observed at lower levels of nutrients with the inoculation of VAM alone. Economic evaluation revealed that $50 \% \mathrm{~N}$ and $\mathrm{P}$ applications along with VAM inoculation gave the maximum net return and cost benefit ratio.

Badawy et. al. (2007) in their study including four clones of sweet potato (Assiut 201, 202, 203 and 204) investigated the effect of five nitrogen fertilizers zero. $25,50,75$ and $100 \%$ of the recommended rate with an equal amount of Biogen fertilizers $(2 \mathrm{~kg})$. The results indicated that the treatment of $(100 \% \mathrm{~N}+2 \mathrm{~kg}$ Biogen) 
gave the best results in most studied characters. Clones Assiut 201 and 204 were the best clones for most studied characters. The $100 \% \mathrm{~N}$ level with Biogen fertilizer gave the best results in most characters. Also, the interaction between (100 N + Biogen) and clone Assiut 204 gave the highest plant height and highest number of branches while the interaction between $100 \% \mathrm{~N}+$ Biogen and clone Assiut 201 gave the best number of marketable storage roots / plant,weight of marketable storage roots / plant, root length and root diameter. Mean while, the highest starch root percentage was obtained from the interaction between 25 and $75 \% \mathrm{~N}+$ Biogen and clone Assiut 201.

The aim of this study was to investigate the effect of chemical NPK, bio and organic fertilizers on yield and yield components of sweet potato c.v. "Mabrouka" under El-Minia growing conditions. Moreover, this study aimed to investigate the possibility of reducing the amount of the chemical NPK fertilizers required by plants . Such studies could be from using mineral fertilizers minimizing the environmental pollution and the risk on human and animal health.

\section{MATERIALS AND METHODS}

The present study was carried out in the two successive seasons of 2008 and 2009 at the Research Farm of the Faculty of Agriculture, EL-Minia University, EL- Minia Egypt. Soil physical and chemical properties are presented in Table 1.

Table 1. Chemical and mechanical analysis of the experimental soil in the two studied seasons.

\begin{tabular}{|c|c|c|}
\hline \multirow{2}{*}{ Properties } & \multicolumn{2}{|c|}{ Season } \\
\cline { 2 - 3 } & 2008 & 2009 \\
\hline Sand \% & 24.01 & 28.53 \\
Silt \% & 29.30 & 27.92 \\
Clay \% & 45.61 & 42.37 \\
Texture grade & Silty clay & Silty clay \\
Organic matter \% & 1.86 & 1.88 \\
pH (1 : 2.50) & 7.86 & 7.99 \\
Total N (ppm) & 30 & 40 \\
Exchangeable K (ppm) & 520 & 480 \\
Available P (ppm) & 2.90 & 2.86 \\
E.C. mmhos/cm 1 : 2.5 & 1.02 & 1.11 \\
\hline
\end{tabular}


Eight fertilizer treatments were used in the present investigation as follow:

1- Recommended rate of the chemical NPK fertilizers.

2- Half rate of the chemical NPK fertilizers (20.6 N: $\left.31 \mathrm{P}_{2} \mathrm{O}_{5}: \mathrm{K}_{2} \mathrm{O}\right)$.

3- Compost (4.28 t / Feddan ) .

4- Bio-fertilizer (Bacterial Azotobacter + Bacillus megatherium var. phosphaticum).

5- Half of recommended rate of NPK + Compost.

6- Compost + Bio-fertilizer.

7- Half of recommended rate of NPK + Bio-fertilizer.

8- Half of recommended rate of NPK + Compost + Bio-fertilizer.

The chemical NPK recommended rate was consisted of $100 \mathrm{~kg}$ ammonium sulphate $(20.6 \% \mathrm{~N}), 200 \mathrm{~kg}$ super phosphate $\left(15.5 \% \mathrm{P}_{2} \mathrm{O}_{5}\right)$ and $100 \mathrm{~kg}$ of potassium sulphate $\left(48 \% \mathrm{~K}_{2} \mathrm{O}\right)$ per feddan. The NPK fertilizer treatments were two equal doses which applied after 30 and 60 days from planting date. Organic fertilizers were incorporated into the soil in the assigned experimental units 3 days before planting date at the rate of 4.28 tons/fed of compost, respectively. The properties analysis of compost is presented in Table (2). Bio-fertilizer (mixture of Bacillus megatherium and Azotobactere) provided kindly from Prof. Dr. Omar Dakhly, Genetic Department, Fac. of Agriculture, EL- Minia University. Bio-fertilizers were incorporated into the soil of the specific experimental units twice i.e., 4 days and 30 days after planting date in both seasons.

Six flasks, each contain $500 \mathrm{ml}$ liquid complete media, three of them were used for growing Azotobacter strain where the other three flasks were inoculated with the Bacillus megatherium var phosphaticum_and all of them incubated at $28^{\circ} \mathrm{C}$ for 5 days, The growth diluted with water before using ( $1: 99 \mathrm{v} . / \mathrm{v}$. ) and mixing with them.

Harvest was done at one time for all treatments, where plants of three ridges of each experimental unit were harvested.

Stem cutting of about $20 \mathrm{~cm}$ length of c.v. "Mabrouka" were planted on the $20^{\text {th }}$ and $25^{\text {th }}$ of May, 2008 and 2009, respectively.

The experimental design was in a complete randomized blocks system in 3 replicates. Each experimental plot was $7.35 \mathrm{~m}^{2}$ which consisted of 3 ridges of $3.5 \mathrm{~m}$ long and $70 \mathrm{~cm}$ wide. Stem cutting were planted in the north side at the ridges at 20 $\mathrm{cm}$ a part . The experimental site was the same in both season.

All agricultural practices known for commercial sweet potato production with the exception of fertilizers were followed. 
Table 2. Properties analysis of compost used in the present study.

\begin{tabular}{|c|c|}
\hline Properties & Compost \\
\hline Organic matter \% & 25.2 \\
Total Nitrogen \% & 1.40 \\
P \% & 0.64 \\
K \% & 0.79 \\
Fe (ppm) & 630 \\
C/N & 1.19 \\
pH & 6.6 \\
\hline
\end{tabular}

The following data were recorded at each harvest time for each experimental unit: 1- Number of storage roots / plant (NRP) .

2- Total storage roots fresh weight / plant (RFWP) in grams.

3- Average root fresh weight (ARFW).

4- Root dry weight / plant (RDWP), in grams.

5- Total dry weight / plant (TDWP) in grams where,

TDWP = VDWP + RDWP, where VDWP is the vegetative dry weight per plant.

6- Harvest index (HI), where:

$$
H I=\frac{\text { RDWP }}{\text { TDWP }} \times 100
$$

\section{Statistical analysis:-}

Data of the studied characters were statistically analyzed and treatments means were compared using Duncan's methods and differentiated using LSD method as described by Steel and Torrie (1980).

\section{RESULTS AND DISCUSSION}

\section{Number of storage roots/plant (NRP):}

Data of this character are shown in Table (3). Number of storage roots / plant was significantly affected by the fertilizer treatments in the two seasons. In this regards, the highest number of roots were produced from plants fertilized with the compost only ( $5.147 \pm 0.3458$ ) in the first season and plants fertilized with the combined application of half rate of the recommended NPK + compost + bio-fertilizer $(6.103 \pm 0.5675)$ in the second seasons. 
Table 3. Effect of fertilization treatments on number of storage roots / plant (NRP) in the two successive seasons of 2008 and 2009.

\begin{tabular}{|l|c|c|}
\hline fertilizers treatments & $1^{\text {st }}$ season (2008) & $\begin{array}{c}2^{\text {nd }} \text { season } \\
(2009)\end{array}$ \\
\hline 1- Recommended rate of NPK & 3.628 & 4.200 \\
\hline 2- Half rate of NPK (Half NPK) & 3.480 & 3.477 \\
\hline 3- Compost. & 5.147 & 5.283 \\
\hline 4- Bio-fertilizer & 4.460 & 4.560 \\
\hline 5- - Half NPK + compost & 2.897 & 5.160 \\
\hline 6- Compost + Bio-fertilizer & 3.690 & 4.417 \\
\hline 7- Half NPK + Bio-fertilizer & 3.290 & 3.357 \\
\hline 8- Half NPK + Compost + Bio-fertilizer & 4.433 & 6.103 \\
\hline L.S.D. & 0.3458 & 0.5675 \\
\hline
\end{tabular}

\section{Average root fresh weight (ARFW):}

Data of this character are presented in Table (4). The obtained results of the effect of the studied fertilizer treatments indicated that the highest values of ARFW were obtained from plants which fertilized with half NPK+ compost $(286.1 \pm 18.07)$ in the first season, but in the second season the highest values of ARFW were obtained from plants fertilized with the half rate of the chemical NPK fertilizers (184.5 \pm 12.63$)$.

These results indicate the importance of different organic and chemical fertilizers on enhancing the vegetative growth and hence increasing the photosynthetic rate. Moreover, organic fertilizer may enhance the storage roots sink capacity which led to increase ARFW.

Table 4. Effect of fertilization treatments on average root fresh weight (ARFW) in the two successive seasons 2008 and 2009.

\begin{tabular}{|l|c|c|}
\hline fertilizers treatments & $1^{\text {st }}$ season (2008) & $2^{\text {nd }}$ season (2009) \\
\hline 1- Recommended rate of NPK & 229.0 & 125.5 \\
\hline 2- Half rate of NPK (Half NPK) & 165.0 & 184.5 \\
\hline 3- Compost. & 158.0 & 103.0 \\
\hline 4- Bio-fertilizer & 187.9 & 124.0 \\
\hline 5- - Half NPK + compost & 286.1 & 125.7 \\
\hline 6- Compost + Bio-fertilizer & 208.8 & 123.2 \\
\hline 7- Half NPK + Bio-fertilizer & 222.8 & 106.6 \\
\hline 8-Half NPK+ Compost+ Bio-fertilizer & 156.5 & 109.1 \\
\hline L.S.D. & 18.07 & 12.63 \\
\hline
\end{tabular}




\section{Storage total root fresh weight per plant (RFWP) in grams:}

Data of this character as affected by the studied fertilizer treatments in the two studied seasons are presented in Table (5).

The obtained data of the RFWP as affected by the fertilization treatments declare that the highest values were obtained from plants fertilized with the compost only in the first season $(720.0 \pm 21.03)$ and half NPK + compost $(634.1 \pm 21.95)$ in the second season.

Table 5. Effect of fertilization treatments on average root fresh weight per plant (RFWP) in the two successive seasons of 2008 and 2009.

\begin{tabular}{|l|c|c|}
\hline fertilizers treatments & $1^{\text {st }}$ season (2008) & $2^{\text {nd }}$ season (2009) \\
\hline 1- Recommended rate of NPK & 543.0 & 530.2 \\
\hline 2- Half rate of NPK (Half NPK) & 480.4 & 609.8 \\
\hline 3- Compost. & 720.0 & 521.9 \\
\hline 4- Bio-fertilizer & 590.8 & 534.1 \\
\hline 5- - Half NPK + compost & 374.2 & 634.1 \\
\hline 6- Compost + Bio-fertilizer & 550.5 & 518.8 \\
\hline 7- Half NPK + Bio-fertilizer & 488.3 & 329.1 \\
\hline 8- Half NPK + Compost + Bio-fertilizer & 52106 & 622.9 \\
\hline L.S.D. & 21.03 & 21.95 \\
\hline
\end{tabular}

Root dry weight per plant (RDWP) in grams:

Data of the effect of fertilization treatments on the root dry weight per plant (RDWP) in the two studied seasons are presented in Table (6). However, the highest value in the first season was obtained from plants fertilized with half NPK + compost (26.12 \pm 1.806$)$ but only the biofertilizer in the second season gave the highest value $(26.53 \pm 2.525$ ).

Table 6. Effect of fertilization treatments on Root Dry Weight / Plant (RDWP) in grams in the successive seasons of 2008 and 2009

\begin{tabular}{|l|c|c|}
\hline fertilizers treatments & $1^{\text {st }}$ season (2008) & $2^{\text {nd }}$ season (2009) \\
\hline 1- Recommended rate of NPK & 23.65 & 23.91 \\
\hline 2- Half rate of NPK (Half NPK) & 23.45 & 23.78 \\
\hline 3- Compost. & 24.98 & 26.05 \\
\hline 4- Bio-fertilizer & 25.58 & 26.53 \\
\hline 5- - Half NPK + compost & 26.12 & 23.59 \\
\hline 6- Compost + Bio-fertilizer & 25.14 & 24.13 \\
\hline 7- Half NPK + Bio-fertilizer & 24.27 & 24.16 \\
\hline 8- Half NPK + Compost + Bio-fertilizer & 25.16 & 23.87 \\
\hline L.S.D. & 1.806 & 2.525 \\
\hline
\end{tabular}




\section{Total dry weight per plant (TDWP):}

Data of this character as affected by the studied fertilization treatments in the two studied seasons are presented in Table (7).

Table 7. Effect of fertilization treatments on Total Dry Weight / plant (TDWP) in grams, in the two successive seasons of 2008 and 2009.

\begin{tabular}{|l|c|c|}
\hline fertilizers treatments & $1^{\text {st }}$ season (2008) & $2^{\text {nd }}$ season (2009) \\
\hline 1- Recommended rate of NPK & 278.3 & 264.3 \\
\hline 2- Half rate of NPK (Half NPK) & 234.3 & 212.9 \\
\hline 3- Compost. & 262.2 & 296.8 \\
\hline 4- Bio-fertilizer & 291.0 & 251.9 \\
\hline 5- - Half NPK + compost & 272.8 & 259.1 \\
\hline 6- Compost + Bio-fertilizer & 297.1 & 277.5 \\
\hline 7- Half NPK + Bio-fertilizer & 159.9 & 191.1 \\
\hline 8- Half NPK + Compost + Bio-fertilizer & 276.2 & 265.4 \\
\hline L.S.D. & 5.625 & 5.008 \\
\hline
\end{tabular}

In regards to the effect of the studied fertilizers treatments, data declared significant effect on TDWP in both seasons. The obtained results declared that the highest values of TDWP were obtained from plants fertilized with compost and biofertilizer in the first season $(297.1 \pm 5.625)$ and only compost $(296.8 \pm 5.008)$ in the second season.

\section{Harvest index (HI):}

Data of the effect of the studied fertilizers treatments on the harvest index in both studied seasons are presented in Tables (8).

Table 8. Effect of fertilization treatments, Harvest Index (HI) in the two successive seasons of 2008 and 2009

\begin{tabular}{|l|c|c|}
\hline fertilizers treatments & $1^{\text {st }}$ season (2008) & $2^{\text {nd }}$ season (2009) \\
\hline 1- Recommended rate of NPK & 39.22 & 48.56 \\
\hline 2- Half rate of NPK (Half NPK) & 38.73 & 45.93 \\
\hline 3- Compost. & 39.20 & 39.11 \\
\hline 4- Bio-fertilizer & 49.17 & 45.45 \\
\hline 5- - Half NPK + compost & 34.40 & 36.19 \\
\hline 6- Compost + Bio-fertilizer & 35.80 & 38.29 \\
\hline 7- Half NPK + Bio-fertilizer & 38.52 & 38.45 \\
\hline $\begin{array}{l}\text { 8- Half NPK + Compost + Bio- } \\
\text { fertilizer }\end{array}$ & 36.38 & 42.69 \\
\hline L.S.D. & & \\
\hline
\end{tabular}


The highest value of $\mathrm{HI}$ in the first season was obtained when plants fertilized with bio-fertilizer $(49.17 \pm 3.097)$ in the first season and the recommended rate of NPK in the second season (48.56 \pm 2.226$)$.

Nair and Vimala (1991) studied the effect of NPK fertilizers using some sweet potatoe cultivars and hybrids. The authors declared that root tuber yield did not vary significantly with the NPK application rates of $75 \mathrm{~kg} \mathrm{~N}+50 \mathrm{~kg} \mathrm{P}+75 \mathrm{~kg} \mathrm{~K} / \mathrm{ha}$ and $50 \mathrm{~kg} \mathrm{~N}+37 \mathrm{~kg} P+50 \mathrm{~kg} \mathrm{~K} / \mathrm{ha}$. Dayal and Sharma (1993) reported that application of $40 \mathrm{~kg} \mathrm{~N}+25 \mathrm{~kg} \mathrm{P}+40 \mathrm{~kg} \mathrm{k} / \mathrm{ha}$ significantly increased marketable root tuber yields of sweet potato from $6.9 t$ (without fertilizer) to $11.3 \mathrm{t}$.

Etman et. al. (2002) reported that application of high NPK fertilizer levels of $135,202.5$ and $270 \mathrm{~kg}\left(\mathrm{~N}-\mathrm{P}_{2} \mathrm{O}_{5}-\mathrm{K}_{2} \mathrm{O} /\right.$ fed $)$ increased leaf blades contents of $\mathrm{N}, \mathrm{P}$ and $\mathrm{K}$ as well as roots dry matter. Moreover, the high NPK fertilizer level (202.5 and 270 $\mathrm{kg} / \mathrm{fed}$ ) raised the values of the vegetative parameters.

Dakly et. al.(' 1993) and Fouly et. al.(' 2002) Estimaed the effectiveness of Azotobacter chroococcum transformants on growth and yield of some vegetable crops.

Rizk et. al. (2003) found that application of the chemical fertilizer (NPK) resulted in having the best growth characters, the heaviest yield weight (11.73 and 12.35 ton/fed. for the first and second seasons, respectively), number and size of tuber was also affected significantly with the studied treatments.

\section{CONCULUSION}

The obtained results from both seasons indicated that the old popular consumption sweet potato cultivar " Mabrouka" was suitable and is recommended for further studies under low input production system ( organic culture ) for its popularity high yield and root tuber quality .

\section{REFERENCES}

1. Abdel-Rahem , A .T. , R .A. Ragab , O. F. Dakhly and R. A. Eid. 1995. Improvement of Azotobacter vinelandii efficiency for nitrogen fixation through mutation induction and conjuation . Egypt, J.Appli.Sci.,10 ( 8 ) : 753771.

2. Abou-Hussein, S. D. 2005. Yield and quality of potato crop as affected by the application rate of potassium and compost in sandy soil. Annals Agric. Sci. Cairo, 50(2): 573-586. 
3. Abou-Hussein, S. D., I. El-Oksh, T. El-Shorbagy and U. A. El-Bahiry. 2002. Effect of chicken manure, compost and biofertilizers on vegetative growth, tuber characteristics and yield of potato crop. Egyptian. J. of Horticulture, 29(1): 135-149.

4. Asenov, R. and N. Matakov. 1985. Effect of mineral and organic fertilizer on yield and quality of potato seed tubers. Rasteniev dminauki, 22: 48-53. (C.F. Potato Abst., 12, 458).

5. Badawy, A. S., M. H. Hosseny and H. E. Mohamed. 2007. Response of some sweet potato lines to biofertilization under drip irrigation in newly reclaimed soil. J. Agric. Sci. Mansoura Univ., 32(4): 2817-2826.

6. Crossman, S. M. and W. R. Hill. 1987. Inoculation of sweet potato with Azospirillum. Hort. Science, 22:420-422.

7. Dakhly. O. F. and Y. T. Abdel - mageed. 1997. Estimation of effectiveness of Azotobacter chroococcum transformants on growth and yield of some vegetable crops Egypt, J. Genet. Cytol., $26: 73-88$.

8. Dayal, T. R. and R. P. Sharma. 1993. Response of sweet potato (Ipomoea batatas) to fertilizers method, time of planting and spacing. Indian, J. Agronomy, 38(3): 431-435.

9. Desmond, G. and A. H. Walter. 1990. Sweet potato growth and nitrogen content following nitrogen application and inoculation with Azospirillum. Hort. Science, 25(7): 758-659.

10. El-Sayed, H. A., A. H. A. El-Morsy and H. M. B. El-Metwally. 2007. Effect of some organic fertilization sources and micronutrient application methods on yield and quality of potato (Solanum tuberosum, L.). J. Agric. Sci., Mansoura Univ., 32(9): 7561-7574.

11. Etman, A. A., N. A. Hassan, M. M. Saffan And M. A. Sharaf El-Din. 2002. Response of sweet potato growth and productivity to varying fertilizer levels and transplanting. International Conf. Hort. Sci., 10-12 Sept. 2002, Kafr ElSheikh, Tanta Univ., Egypt. P. 142-151.

12. Fouly, H. M. H., O. F. Dakhly, El-M. A. Awad , Y. T. Abdel-Mageed and E. A. Hassan. 2002 . Using some isolates and transforments of Azotobacter to reduce chemical nitrogen fertilizer rates in garlic production .J. Agric . Sci., Mansoura UNIV. , 27 ( 11) : 7667 - 7684 .

13. Hill, W. A., D. G. Mortley. and S. M. Crossman. 1988. Fertilizer N independent and dependent sweet potato cultivars. In: VII the symposium of the International Society for Tropical Root Crops, Gosier (Guadeloupe), 16 July, INRA-Paris. P 703-713. 
14. Indiresh, K. M., K. R. Sreeramulu , S. V. Patil and Venkatesh. 2003. Response of potato to biofertilizers at graded levels of chemical fertilizers. Indian Potato Assoc. 30(1/2): 79-80.

15. Jadhav, A. C., S. A. Memane and B. K. Knode. 1998a. Evaluation of biofertilizers in respect to growth and yield attributing parameters in sweet potato. J. of Maharashtra Agricultural Universities, 23 (1): 80-82.

16. Jha, R. K. and S. Mishra. 1999. Effect of Azospirillum inoculation on nitrogen fixation and growth of sweet potato (Ipomoea batatas L. ). J. of Applied Biology, 9(1): 49-51.

17. Kleinhenz, M.D. and J. Cardina. 2003. Compost application effects on weed populations and crop yield and quality in thee early-maturing, organicallymanaged potato (Solanum tuberosum) cultivars. Act Hort. (619): 339-343.

18. Kloos, J. P. 1986. Nitrogen and Phosphorus requirements for potato production on an adtuyon clayin bukidnon Philippines. Philippine Agriculturist, 69(2): 251-262.

19. Kulakovskya, T. N. and I. I. Brysovskii. 1984. Increasing potato yield and quality through fertilization. Soviet. Agriculture Science. No 6 (1-4).

20. Mac Donald, A. S. 1963. Sweet potatoes with particular reference to the tropics. (C.F. Field crop Abst., 16: 219-225).

21. Marcano, A. J. J. and L. A. J. Diaz. 1994. Effect of application of six combinations of $\mathrm{N}, \mathrm{P}$ and $\mathrm{K}$ on yield of roots and foliage of sweet potatoes. Agronomia. Tropical. Maracay, 44(2): 317-335.

22. Nair, T. V. R. and B. Vimala. 1991. Evaluation of some promising genotypes of sweet potato as influenced by levels of NPK fertilization. J. Root Crops, 17:108-111.

23. Nwinyi, S.C.O.1988. Fertilizer placement methods for sweet potato (Ipomoea batatas L.) . Beitrage Zur Tropischen Landwirtschaft and verterinarmedizin 26(4): 359-365. (C.F. Soils and Fertilizers, 52(10), 11819.

24. Pushpakumari, R. and V.L. Geethakumari. 1999. Economizing N and P through combined inoculation of Mycorrhiza and Azotobacter in sweet potatoes. J. Root Crops., 25(1): 69-71.

25. Rasco,E. T., V. D. Amante, E. Orolfo and M. Catanay. 1992. Response of sweet potato to biofertilizers Special. Publication Taichung District. Agricultural Improvement station., No. 29, 404-417, (C.F. Dialog Information Services. (CAB, Abst. Database). 
26. Rizk, F. A., H. M. H. Foly and M. R. Shafeek. 2003. The productivity of potato yield and its quality as influenced by the application of different nitrogen sources. J. Agric. Sci. Mansoura Univ., 28(2): 1281-1290.

27. Sarhan, S. H., H. K. Zaki and E. N. El-Banna. 2004. Impact of organic and inorganic fertilization on yield, under contents and some heavy metals concentration in potato tubers. J. Agric. Sci Mansoura Univ., 29(5):2753-2760.

28. Steel, R. G. D. and J. H. Torrie. 1980. Principles and Procedures of Statistics A Biometrical Approach MC. Graw Hill Book Company (2nd Ed.), N.Y. 631P.

29. Subba Rap, N. S. 1984. Bio-fertilizers in Agriculture. Oxford \& IBh Publishing CO., New Delhi, India.

30. Syriac, E. and U. M. Kunju. 1989. Response of sweet potato (Ipomoea batatas L.) to NPK in the reclaimed alluvial soils of Kuttanad, Kerala. J. Root crops, 15(2): 91-95.

31. Tashkhodzhaev, A. T. 1985. Effect of organic fertilizer on potato yield and quality on seven soils. Agrokhimiya, 11:71-85. 


\title{
تأثير المعاملات السمادية الكيماوية و الحيوية و العضوية على الحصاد ومحصول البطاطا
}

\author{
حسن محمد حسن فولي 1 ، 2حسن سيد توني ، عمر فتحي داخلي 3 \\ 1. الدعمل المركزي للزراعة العضوية - معهد بحوث البساتين - مركز البحوث الزراعية - الجيزة. \\ 2. معرة بحوث البساتين - مركز البحوث الزراعية - الجبزة. \\ 3. قسم الوراثة - كلبة الزراعة - جامعة المنيا.
}

أجريت التجارب الحقلية لهذه الدراسة فى موسمين متتابعين هما

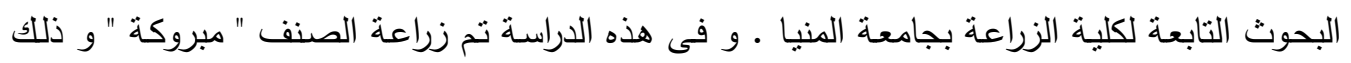

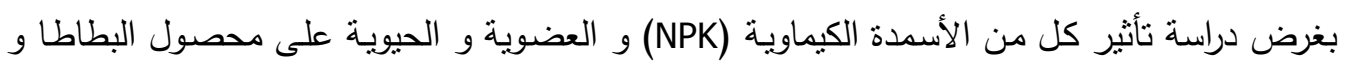

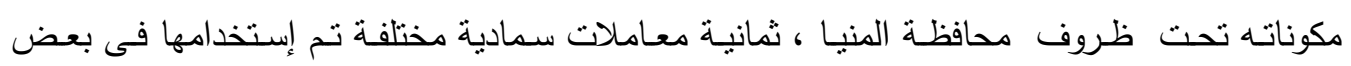
التوليفات الممكنة من بين الأسدة تحت الدانه

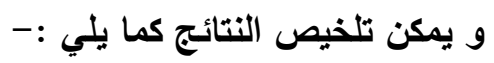

عدد الجذور المخزنة / للنبات قد تأثز بالمعاملات السمادية تأثثراً معنوياً فى كل من موسمي

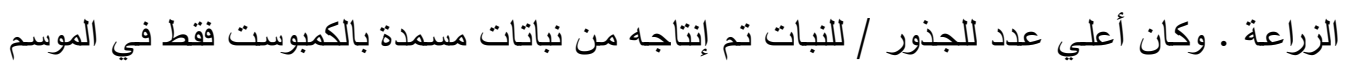

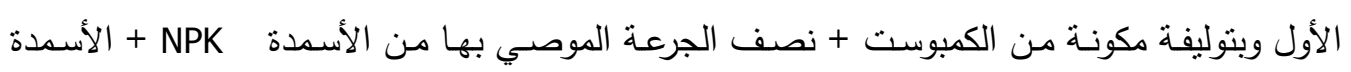

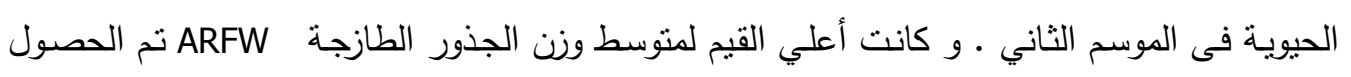

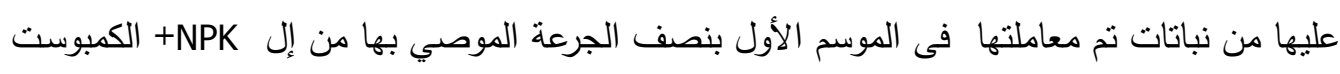

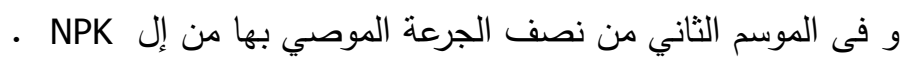

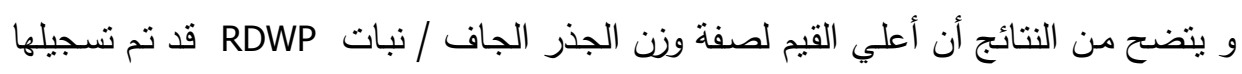

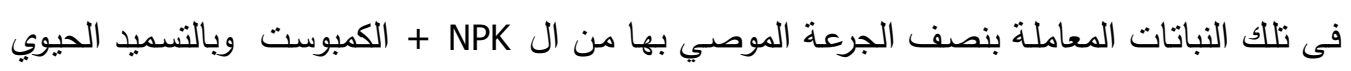
فقط فى الموسم الثاني.و تشير الدراسة أيضاً أن صفة الوزن الجاف الكلي / نبات TDWP تأثز معنويا

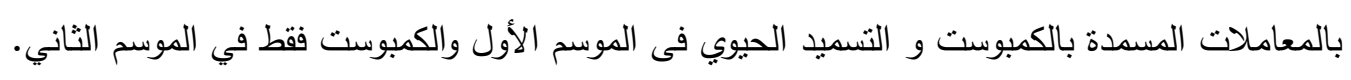

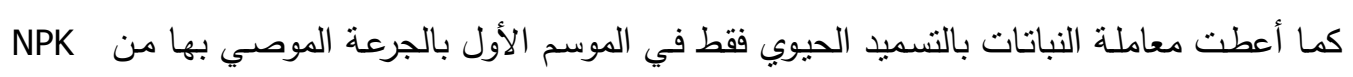

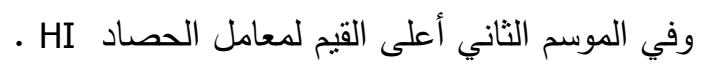

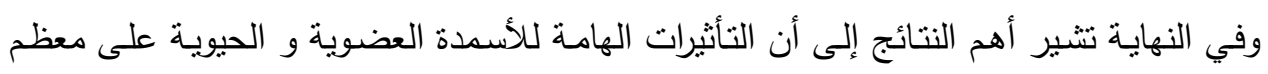
الصفات المحصولية مما يعطي إمكانية إحلال أو خفض جزء من الأسمدة الكيماوية NPK المطلوبة الهية لإنتاج البطاطا باستخدام السماد العضوي و الأسمدة الحيوية. 